\title{
Mass Spectrometric Analysis of a Standard Sample of Carburetted Water-Gas by Laboratories Cooperating With the American Society for Testing Materials
}

\author{
By Martin Shepherd ${ }^{1}$
}

\begin{abstract}
The mass spectrometer was used for the analysis of a standard sample of carburetted water-gas by laboratories cooperating with Subcommittee VII of Committee D-3 of the American Society for Testing Materials. The results of the cooperative analysis show the reproducibility and, in certain respects, the accuracy of this powerful new apparatus for gas analysis. The heating value and the specific gravity of the sample calculated from the analytical data were compared with the known values. Some very creditable work is reported, but the need for improvement and standardization with respect to the determination of hydrogen, carbon monoxide and nitrogen is evident.
\end{abstract}

\section{Introduction}

This report is the fifth of a series of cooperative analyses of standard gas samples ${ }^{2}$ conducted to furnish basic information for the development of standard methods for the analysis of fuel gases. The development of these standards is a task assigned to Subcommittee D-3-VII of the ASTM, and the method of this development has been outlined in four previous reports. ${ }^{3}$

The 27 laboratories that cooperated in the present work were widely distributed geographically, but most of them were associated with the petroleum industry. There was some representation from the chemical industry and Government laboratories. In general, all the laboratories followed the operating procedures prescribed in the manuals furnished with the instruments. Depar-

${ }^{1}$ Chairman of Subcommittee VII (Analysis of Gaseous Fuels) of Committee D-3 (Gaseous Fuels), American Society for Testing Materials.

2 These samples are not to be confused with the regular Standard Samples prepared and offered for sale by this Bureau. They are mixtures prepared especially for these cooperative analyses and are issued to laboratories cooperating with the American Society for Testing Materials on this project.

${ }^{3}$ Martin Shepherd, Analysis of a standard sample of the carburetted watergas type by laboratories cooperating with the American Society for Testing Materials, J. Research NBS 36, 313 (1946) RP1704; Analysis of a standard sample of natural gas by laboratories cooperating with the American Society for Testing Materials, J. Research NBS 38, 19 (1947) RP1759; Cooperative analysis of a standard sample of natural gas with the mass spectrometer, J. Research NBS 38, 491 (1947) RP1789; Analysis of a natural gas by volumetric chemical methods and by mass spectrometer, Anal. Chem. 19.635 (1947). tures from the prescribed course were few and of such nature that no significant change was expected or observed. The greatest variation was in the method of computation. Thus, with respect both to apparatus and methods of operation, this series of cooperative analyses was conducted with a preliminary standardization that was unofficial but none the less real; and, while this may or may not have been a factor in the accuracy achieved, it must have affected the over-all reproducibility. The need for further standardization, particularly in calculating methods, is evident.

\section{Standard Carburetted Water-Gas Sample ASTM D-3-VII-5}

The preparation of the standard sample of the carburetted water-gas type, identified as ASTM D-3-VII-1, which was used in the cooperative analysis by volumetric chemical methods, has been described in detail in Research Paper RP1704 (see footnote 3 ). That account will serve to establish the history of the present sample, ASTM D-3-VII-5, which was analyzed by the mass spectrometer, since the No. 1 and No. 5 samples were identical, except for oxygen, which had been mostly removed from sample 5. This information was not disclosed when sample 5 was issued, and accordingly it was analyzed as a blind sample. 
In general, it did not find its way into the same laboratories that had performed the chemical analyses, although, in a few cases, this did happen.

Sample ASTM D-3-VII-5 was issued in the same type of cylinder as that used for the sample 1 , and the instructions for transferring it to the spectrometer without contamination were essentially the same. This information will, accordingly, not be repeated here.

Chemical and physical methods were thus put into direct competition. The part of the story concerned with the analysis by the mass spectrometer is given in this paper. A comparison of the two methods will be given in another paper.

\section{Analytical Results}

All of the analytical data submitted have been tabulated, together with the average values derived from each laboratory's analyses; but the study of these data for a long time would not serve to reveal what may be seen at a glance when these same data are presented in a series of frequencydistribution plots. These plots, which amount to actual pictures of the analytical results, will enable the reader to arrive at the obvious conclusions.

In the plots, each circle represents a value derived from a single determination of the substance indicated in the legend. The abscissas are values derived from the analyses; and these values are plotted equidistant on the ordinates and so indicate the frequency with which these values occur. For example, the frequency-distribution plot for carbon dioxide (fig. 1) shows that 4 determinations gave the value 4.0 percent, 8 determinations gave 4.1 percent, 4 gave 4.2 percent, 10 gave $4.3,18$ gave 4.4, and so on. The plots are divided into two sections, one of which shows the laboratory averages, the other all of the determinations. Thus a laboratory to laboratory comparison may be made, but the study of accuracy and reproducibility may be referred to the plot giving all determinations. This system is carried throughout the group of plots, and with this in mind, they can be studied. The analyses for each component will be considered.

Carbon Dioxide (fig. 1). All of the determinations for carbon dioxide are given in figure 1 . The greatest frequency is indicated at 4.5 , in agreement with the arithmetical average (determined

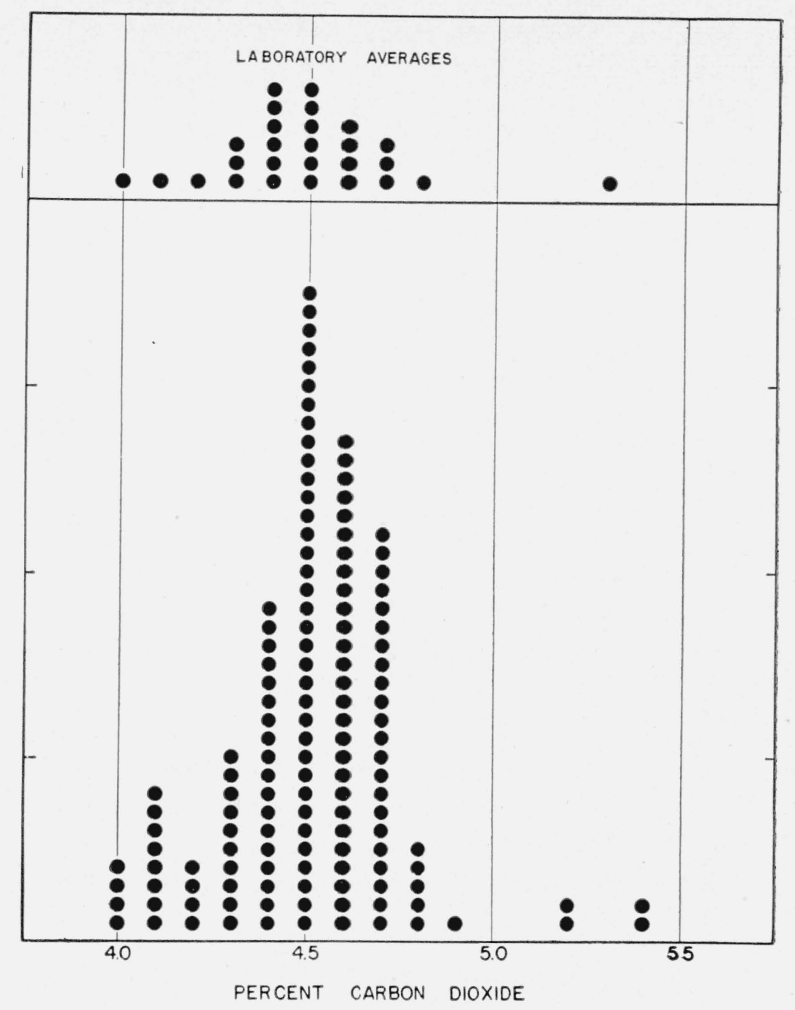

FIGURE 1. Frequency-distribution plot for percentage of carbon dioxide.

with four high values dropped), $4.49 \pm 0.14$ (average deviation), and with the median, 4.5. These values agree with the most probable value, 4.44 \pm 0.04 , previously determined ( $\mathrm{RP} 1704)$. The laboratory average is $4.49 \pm 0.17$ - or, with one high value dropped, $4.46 \pm 0.14$. Accuracy and reproducibility are thus satisfactory.

Oxygen (fig. 2). Oxygen occurred in this sample in an amount less than 0.05 percent, so that rounded off values indicate its absence in 66 percent of the determinations. After dropping the three high values, the arithmetical average becomes 0.03. Highest frequency and median are found at 0 . Laboratory average (without the three high rogues) is 0.03 . Most of the determinations of this gas are satisfactory.

Carbon Monoxide (fig. 3). The spectrometer was not altogether comfortable with respect to this determination. Some analysts calculated from the over-populated though most sensitive 28 peak; a few others used the less sensitive 12 peak. In one case $\mathrm{CO}$ was completely confused with $\mathrm{N}_{2}$. The plot shows no adherence to the Gaussian pattern. The arithmetical mean com- 


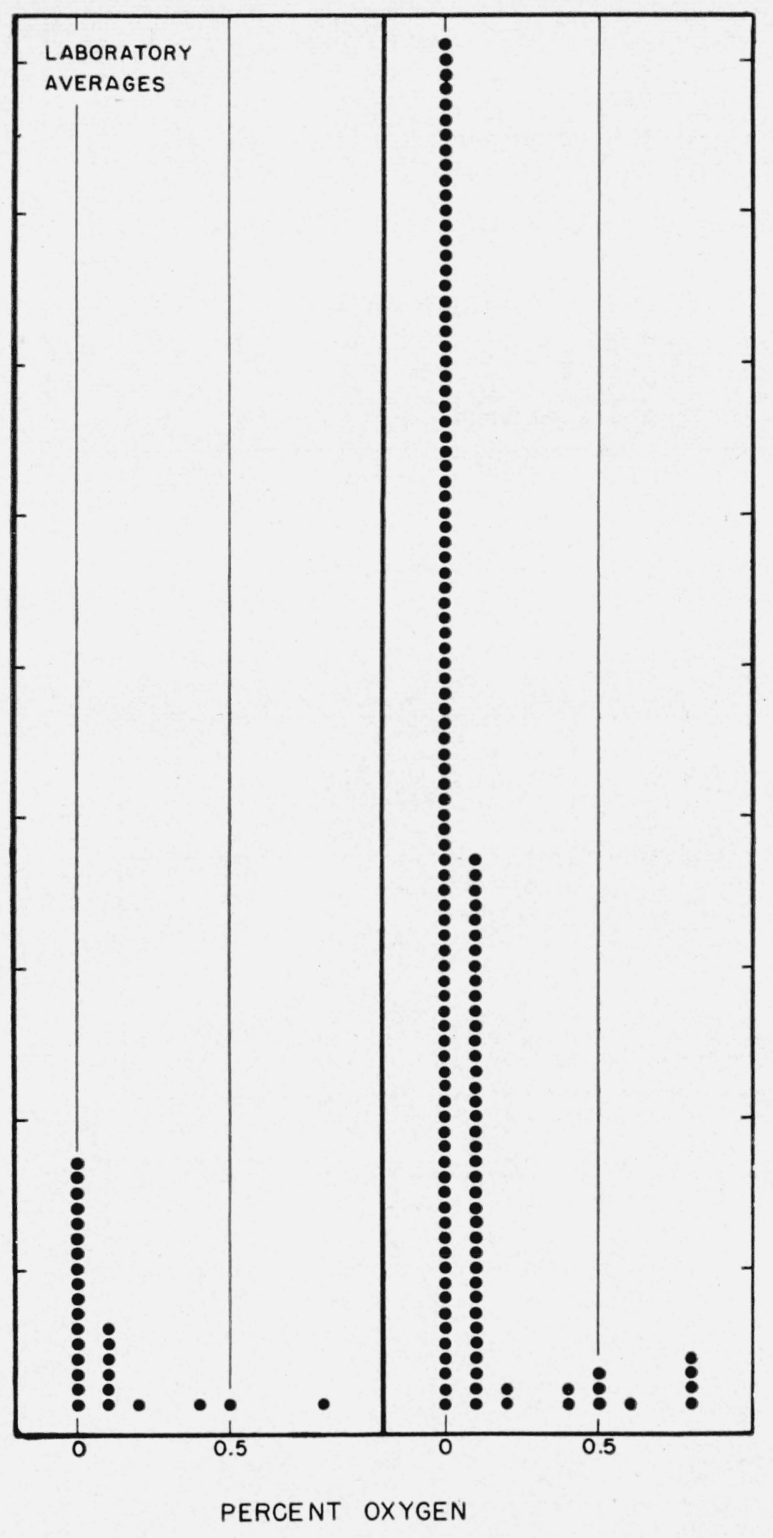

FIGURE 2. Frequency-distribution plot for percentage of oxygen

puted from values between 28.4 and 32.3 , inclusive, is $30.3 \pm 0.9$, which is in reasonable agreement with the chemical determination of 29.41 \pm 0.18 , even though its derivation included a wide variety of values. No highest frequency is apparent; the median is 30.35 . The laboratory averages range from 19.3 to 33.5 (dropping one zero); their average is $29.8 \pm 1.5$. Need for improvement is evident.

Hydrogen (fig. 4). The spectrometer is not altogether happy with this determination, as shown by the far flung values and disregard for the Gaussian shape. The mean, computed from values between 33.0 and 37.8 , inclusive, is $35.1 \pm 0.8$. The median is 35.1 . These values agree well with the chemical determination of 35.0 , even though the derivation was from scattered values. Improvement is needed, and, indeed, some has been achieved since these data were taken. Laboratory averages range from 31.9 to 38.6 ; their average is $35.2 \pm 1.1$.

Methane (fig. 5). While some difficulty was experienced with carbon monoxide and hydrogen in this sample (and more difficulty will occur with nitrogen), the spectrometer is at home in dealing with the hydrocarbon fractions of this gas. The change is evident in the methane plot. The mean (with three low values dropped) is $8.0 \pm 0.4$; the median is 8.0 ; and the highest frequency occurs at 8.1. Laboratory averages range from 6.2 to 9.3 ; their average is $7.9 \pm 0.4$. In general, the values are satisfactorily clustered, and a Gaussian pattern is now evident.

Ethane (fig. 6). A clean-cut analysis for ethane is shown in this plot. The highest frequency occurs at 3.3 . The mean is $3.3 \pm 0.15$, and the median is 3.3. Laboratory averages range from 2.8 to 3.5, with an average of $3.3 \pm 0.15$. The answer seems to be 3.3 .

Ethylene (fig. 7). Determination of the ethylene was not achieved in the decisive manner shown in the determination of the ethane. (In general, this is true of the unsaturated hydrocarbons.) Nevertheless, the determination for ethylene was satisfactory. The plot shows a block-like structure of values centered about 13 percent. The mean is $12.9 \pm 0.4$, and the median is also 12.9 .

Other hydrocarbons reported in small amounts are shown at the right of the plot for ethylene. There are not many, but out of 138 analyses, propane was reported 15 times, propylene 18 times, $n$-butane 6 times, butenes 6 times, " $\mathrm{C}_{3}$ " three times, $\mathrm{C}_{3}+$ heavier hydrocarbons 12 times, and acetylene 3 times.

Nitrogen (fig. 8). The values for nitrogen are sufficiently diverse to be statistically inconvenient from the analyst's viewpoint. The laboratory averages vary from 4.3 to 13.8 (dropping eight values at $36 .+$ ), with an average of $6.4 \pm 0.1$. The mean for all determinations is $5.9 \pm 0.8$, if values from 4.2 to 8.2 , inclusive, are accepted. The pattern is not molded along classical lines. The 


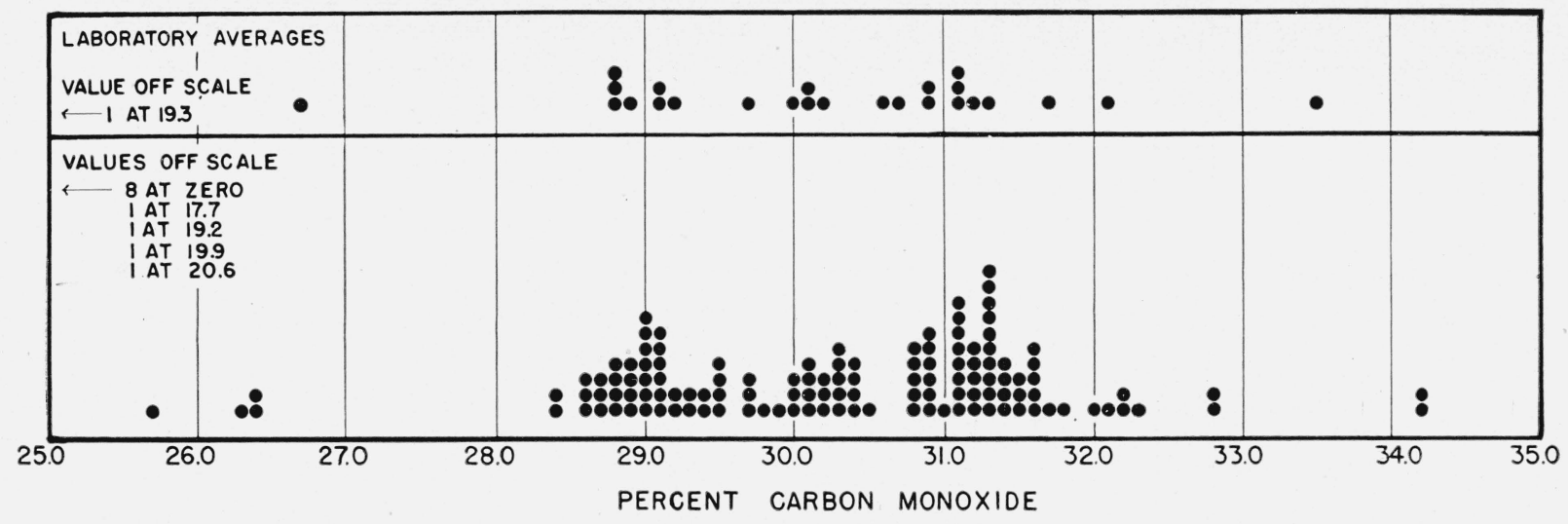

FIGURE 3. Frequency-distribution plot for percentage of carbon monoxide.

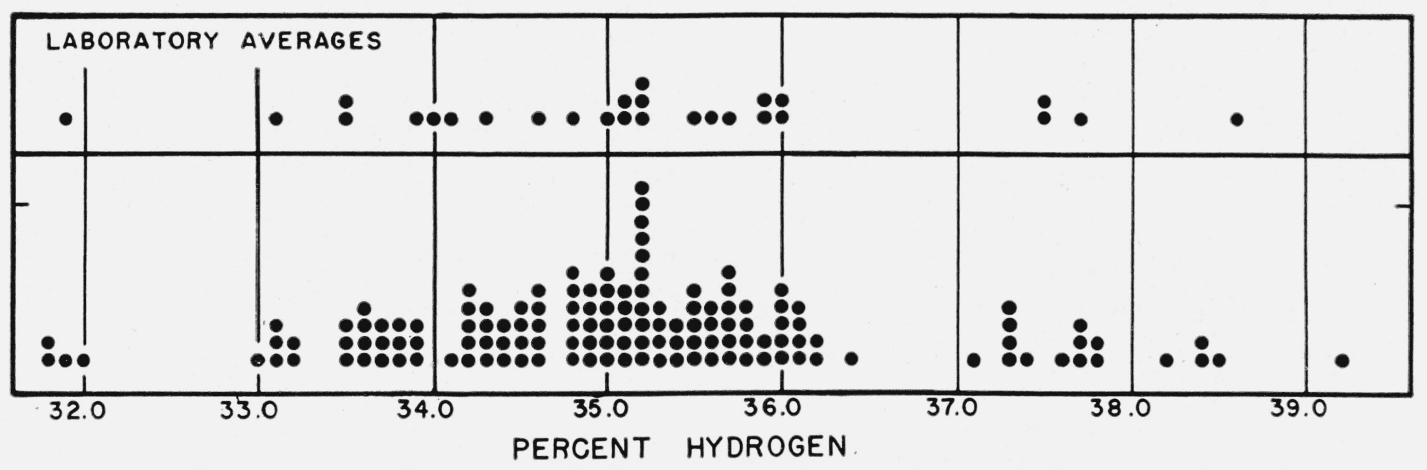

FigURE 4. Frequency-distribution plot for percentage of hydrogen.

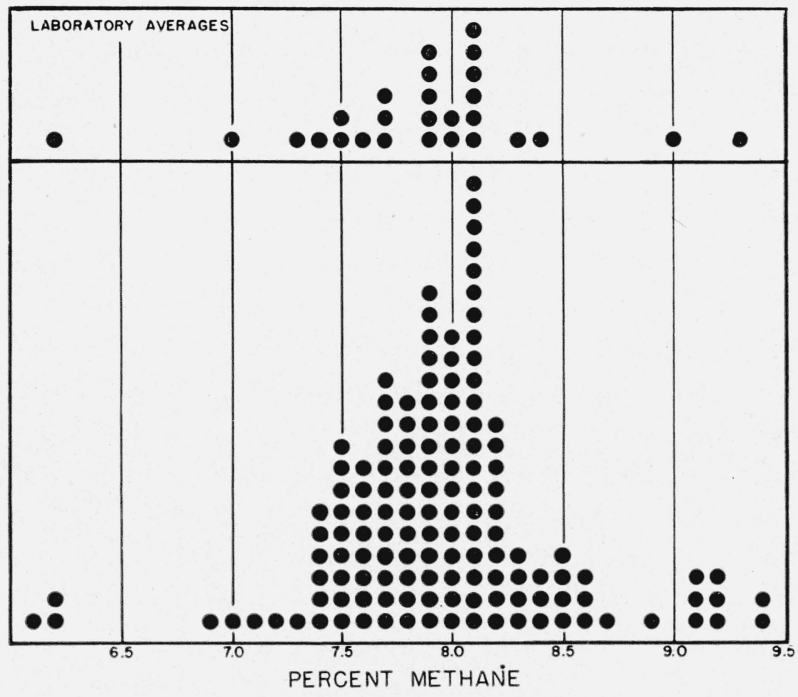

FIGURE 5. Frequency-distribution plot for percentage of methane 


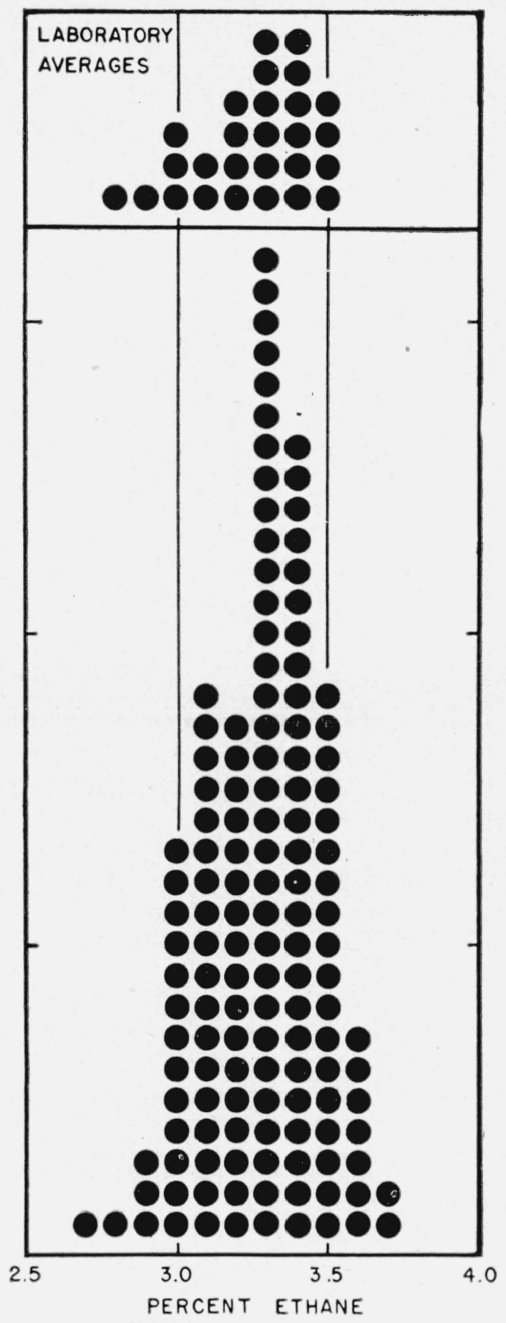

Figure 6. Frequency-distribution plot for percentage of ethane.

median is 5.8, dropping eight values at $36 .+$. The median is nearer the best chemical value of $5.74 \pm 0.06$. Certainly this determination must be improved for this type of gas.

Calculated Specific Gravity (fig. 9). Specific gravity calculated from the mass spectrometric analyses show rogues to both right and left of center. The mean of all values between 0.626 and 0.677 is $0.650 \pm 0.007$; the median is 0.651 . The Gaussian pattern is distorted, with maxima suggested at 0.644 and about 0.651 . Laboratory averages range from 0.617 to 0.676 , with an average of $0.648 \pm 0.009$. The actual measured value for this sample is $0.6475 .^{4}$ It should be remembered

\footnotetext{
4 The specific gravity was measured by Carrol Creitz at this Bureau. The method used is described in NBS Miscellaneous Publication M177 (1947).
}

that calculated specific gravity is a direct over-all measurement of the accuracy of the analysis.

Calculated Heating Value (fig. 10). The plot again shows no decisive Gaussian pattern. The mean of values from 529 to 566 is $550 \pm 7$, and the median is 551. Laboratory average is $547+8$, dropping the value 458 . The measured value is $549 .^{5}$

\section{The Tabulated Data}

No attempt has been made to set forth all of the statistical inferences that can be derived from the data given in this report. The whole object of the report is to present a general integrated picture of the real state of analysis of this kind without, for the moment, distracting particulars. This is not to say that a statistical study will not prove of equal or greater value, but it should be presented separately. To tempt someone to do this, the data are given in table 1 at the end of this paper.

The table is self-explanatory except for the column "Operator-Spectrogram-Calculator Key." The experiment was designed to show the effect of these three factors - the operator of the spectrometer, the instrument itself as indicated by the spectrogram it produced, and the calculator who derived the final answer from the spectrogram. Each laboratory was asked to produce four spectrograms of the standard sample, using two instrument operators and two calculators. The complete pattern for each laboratory should have been

$$
\begin{aligned}
& \mathrm{O} 1-\mathrm{S} 1-\mathrm{C} 1 \\
& \mathrm{O} 1-\mathrm{S} 1-\mathrm{C} 2 \\
& \mathrm{O} 1-\mathrm{S} 2-\mathrm{C} 1 \\
& \mathrm{O} 1-\mathrm{S} 2-\mathrm{C} 2 \\
& \mathrm{O} 2-\mathrm{S} 3-\mathrm{C} 1 \\
& \mathrm{O} 2-\mathrm{S} 3-\mathrm{C} 2 \\
& \mathrm{O} 2-\mathrm{S} 4-\mathrm{C} 1 \\
& \mathrm{O} 2-\mathrm{S} 4-\mathrm{C} 2
\end{aligned}
$$

where $\mathrm{O}$ means operator, $\mathrm{S}$ designates spectrogram, and $\mathrm{C}$, the calculator. The $\mathrm{O}-\mathrm{S}-\mathrm{C}$ key of the table is thus explained. The table discloses only seven complete patterns, while others are partially complete, or not clearly defined.

Before passing these data along to competent statistical talent, a few observations may be briefly made. If the complete patterns for

- The heating value was measured by John Eiseman and Ralph Jessup at his Bureau. 

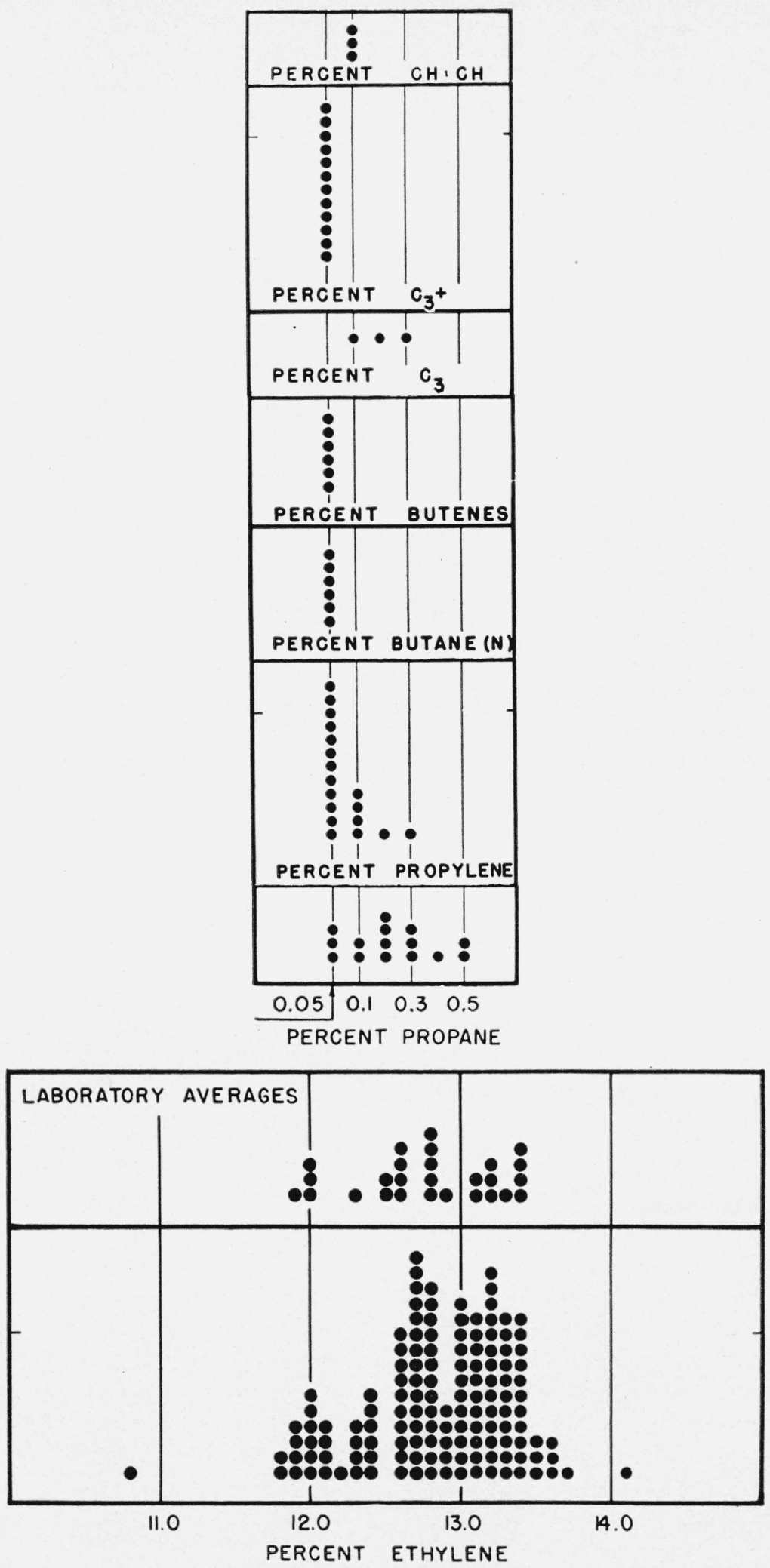

FIGURE 7. Frequency-distribution plots for percentages of ethylene and propane. 


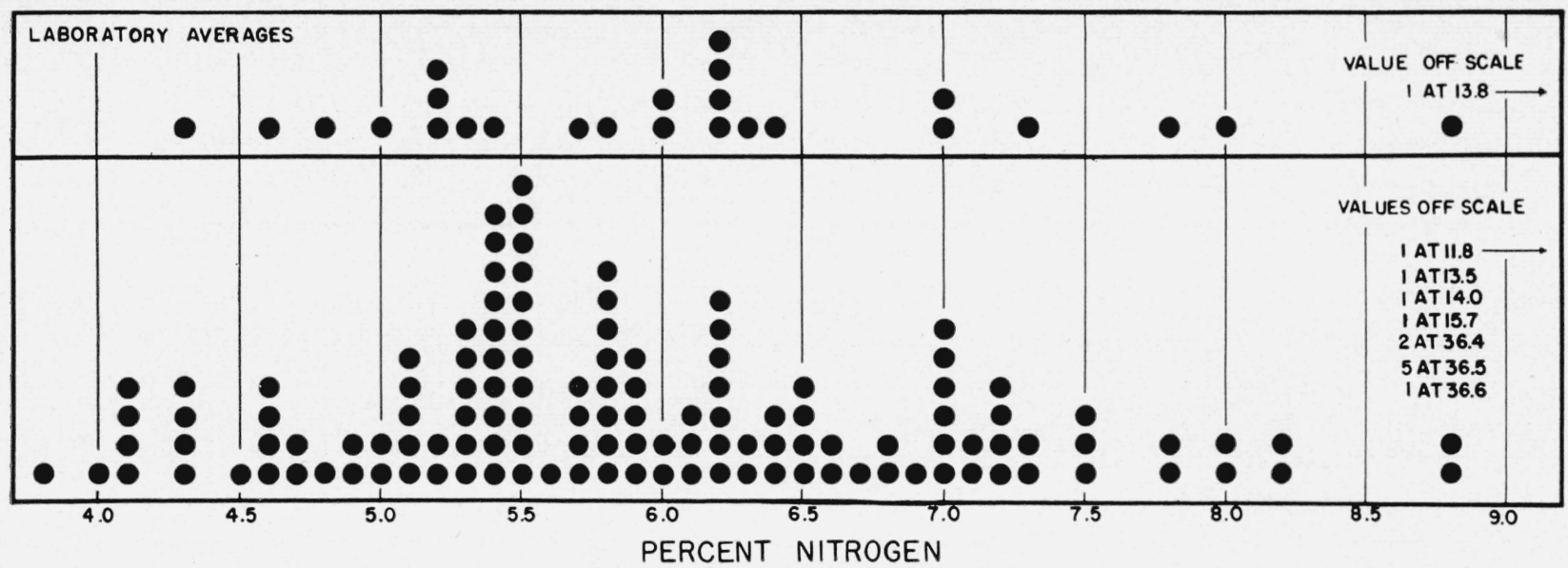

Figure 8. Frequency-distribution plot for percentage of nitrogen.

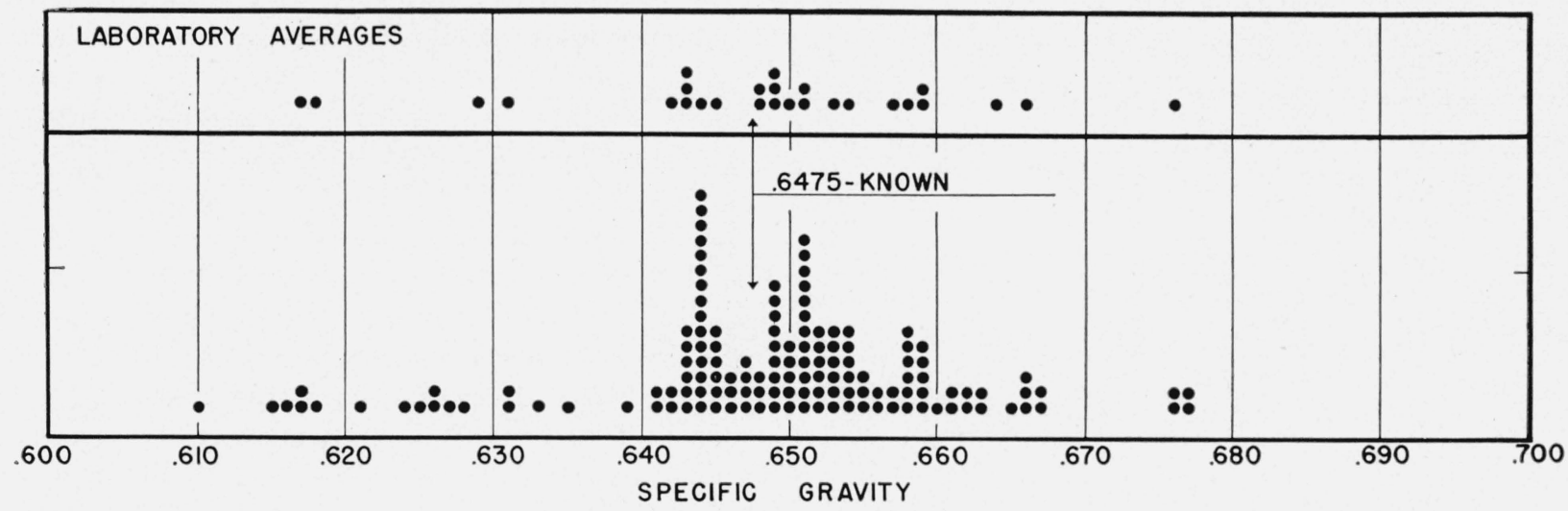

FIGURE 9. Frequency-distribution plot for specific gravity.

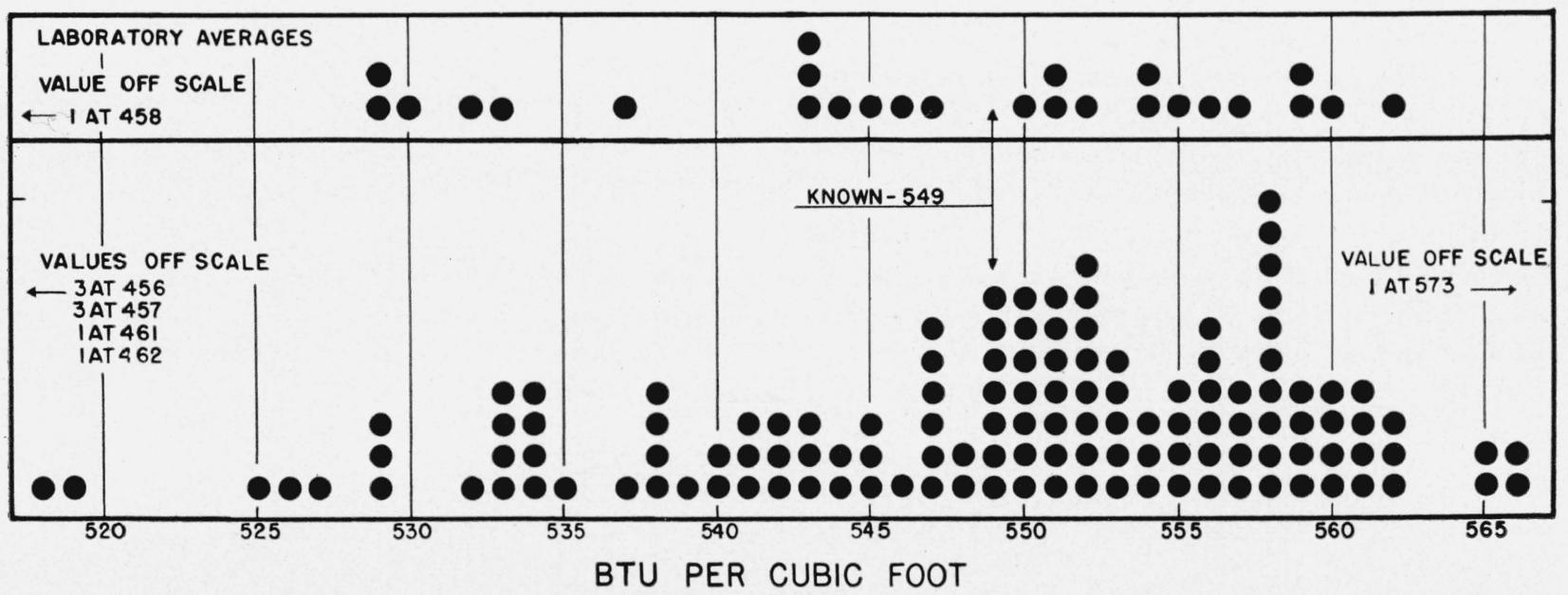

Figure 10. Freguency-distribution plot for Btu per cubic foot.

Mass Spectrometric Analysis of Carburetted Water-Gas 
laboratories $2,4,8,10,11,17$, and 20 are examined in the instance of calculated specific gravity, which is a good over-all measure of the success of the analysis involving all components determined, these facts are evident:

(1) The differences between two calculators using the same spectrogram in the same laboratory were small. The average differences for the seven laboratories (in the order given above), expressed in thousandths, are: $1.1 / 2,0,1,1 / 4$, $41 / 4,1 / 4,11 / 4$; the average of all the differences is 1.2. (This calculation was based on differences between $\mathrm{O} 1-\mathrm{S} 1-\mathrm{C} 1$ and $\mathrm{O} 1-\mathrm{S} 1-\mathrm{C} 2, \mathrm{O} 1-\mathrm{S} 2-\mathrm{C} 1$ and $\mathrm{O} 1-\mathrm{S} 2-\mathrm{C} 2, \mathrm{O} 2-\mathrm{S} 3-\mathrm{C} 1$ and $\mathrm{O} 2-\mathrm{S} 3-\mathrm{C} 2, \mathrm{O} 2-\mathrm{S} 4-$ $\mathrm{C} 1$ and $\mathrm{O} 2-\mathrm{S} 4-\mathrm{C} 2$.)

(2) The differences between two operators using the same instrument in the same laboratory were small. The average differences for the seven laboratories are: $11 / 2,1,1 / 2,1,31 / 2,1 / 4,11 / 4$. The average of all differences is 1 . (This calculation was based on the average of all $\mathrm{O} 1$ measurements minus the average of all $\mathrm{O}^{2}$ measurements for each laboratory).

(3) The differences between spectrograms were larger than between operators and calculators. For the seven laboratories, the average differences are $11 / 2,1,4,41 / 4,41 / 4,13 / 4,11 / 4$. The average of all differences is 2.6. (This calculation was based on the differences between $\mathrm{O} 1-\mathrm{S} 1-\mathrm{C} 1$ and $\mathrm{O} 1-\mathrm{S} 2-\mathrm{C} 1, \mathrm{O} 1-\mathrm{S} 1-\mathrm{C} 2$ and $\mathrm{O} 1-\mathrm{S} 2-\mathrm{C} 2, \mathrm{O} 2-$ $\mathrm{S} 3-\mathrm{C} 1$ and $\mathrm{O} 2-\mathrm{S} 4-\mathrm{C} 1, \mathrm{O} 2-\mathrm{S} 3-\mathrm{C} 2$ and $\mathrm{O} 2-\mathrm{S} 4-\mathrm{C} 2$. See O-S-C key above).

These observations agree with those made previously in the analysis of a natural gas by the mass spectrometer (see footnote 3 ).

In a paper given December 27, 1949 to the 109th annual meeting of the American Statistical Association, W. J. Youden remarked: "It is a fact of experience that a set of measurements made by different operators at different times or in different localities is subject to greater variation than a set of measurements made by one operator using the same apparatus on the same day." The data presented here offer no exception to this fact of experience. Thus, for example, the mean of all values of calculated specific gravity (between 0.626 and 0.677 ) is $0.650 \pm 0.007$; the mean of the laboratory averages is $0.648 \pm 0.009$; but the reproducibility of each laboratory varies from 0.0005 to 0.004 , with an average of 0.0017 - three times better than the reproducibility obtained from the laboratory averages.

The factors controlling interlaboratory differences will probably never be completely evaluated. One important factor in the present case is a difference in methods of solving spectrograms, and not enough is known about this whole subject. Particular attention is being given this phase of mass spectrometric analysis in the preparation of ASTM tentative standards.

\section{Summary}

As often happens, a group of values that yield a frequency plot devoid of the classical Gaussian pattern and are, from the analyst's viewpoint, inconveniently various, nevertheless have yielded a mean value very close to the most probable or the actual one. This is always a comfort if one has an abundance of data from as many sources as are necessary; but the problem remains to determine the accuracy of a single source in the absence of sufficient data from many sources. Thus, the spectrometric determination of hydrogen, and of carbon monoxide with nitrogen, has not been altogether satisfactory. However, the mass spectrometer is quite at home in the analysis of the hydrocarbon fraction of such samples as the one just studied, even though some difficulty was experienced around mass 28 . In fact, the spectrometer is able to analyze actual fuel gases of this type where 20 component mixtures are not unusual. Such complicated mixtures have been difficult when analyzed by a combination of other methods.

Jean Doyle and Marthada Vaughn Kilday checked the calculations of heating value and specific gravity, and this assistance is gratefully acknowledged. 
TABLE 1

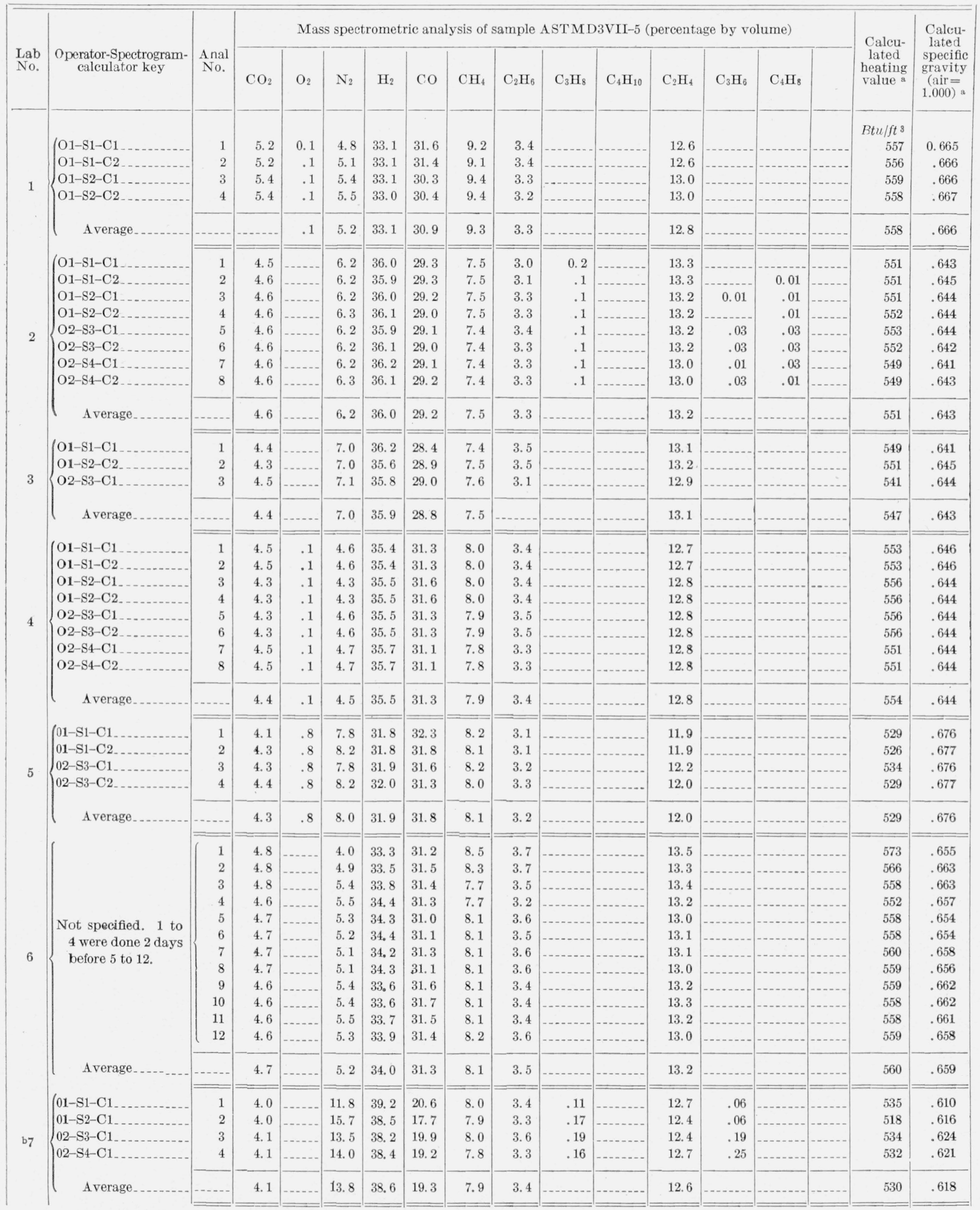

See footnotes at end of table. 
TABLE 1-Continued

\begin{tabular}{|c|c|c|c|c|c|c|c|c|c|c|c|c|c|c|c|c|c|}
\hline \multirow[b]{2}{*}{$\begin{array}{l}\text { Lab } \\
\text { No. }\end{array}$} & \multirow[b]{2}{*}{$\begin{array}{l}\text { Operator-spectrogram- } \\
\text { calculator key }\end{array}$} & \multirow[b]{2}{*}{$\begin{array}{l}\text { Anal } \\
\text { No. }\end{array}$} & \multicolumn{13}{|c|}{ Mass spectrometric analysis of sample ASTMD3VII-5 (percentage by volume) } & \multirow{2}{*}{$\begin{array}{l}\text { Calcu- } \\
\text { lated } \\
\text { heating } \\
\text { value a }^{\text {a }}\end{array}$} & \multirow{2}{*}{$\begin{array}{l}\text { Calcu- } \\
\text { lated } \\
\text { specific } \\
\text { gravity } \\
(\text { air }= \\
1.000) \text { a }\end{array}$} \\
\hline & & & $\mathrm{CO}_{2}$ & $\mathrm{O}_{2}$ & $\mathrm{~N}_{2}$ & $\mathrm{H}_{2}$ & $\mathrm{CO}$ & $\mathrm{CH}_{4}$ & $\mathrm{C}_{2} \mathrm{H}_{6}$ & $\mathrm{C}_{3} \mathrm{H}_{8}$ & $\mathrm{C}_{4} \mathrm{H}_{10}$ & $\mathrm{C}_{2} \mathrm{H}_{4}$ & $\mathrm{C}_{3} \mathrm{H}_{6}$ & $\mathrm{C}_{4} \mathrm{H}_{8}$ & & & \\
\hline \multirow[t]{3}{*}{8} & $\left\{\begin{array}{l}01-\mathrm{S} 1-\mathrm{C} 1 \ldots \\
01-\mathrm{S} 1-\mathrm{C} 2 \\
01-\mathrm{S} 2-\mathrm{C} 1 \\
01-\mathrm{S} 2-\mathrm{C} 2 \\
02-\mathrm{S} 3-\mathrm{C} 1 \\
02-\mathrm{S} 3-\mathrm{C} 2 \\
02-\mathrm{S} 4-\mathrm{C} 1 \\
02-\mathrm{S} 4-\mathrm{C} 2\end{array}\right.$ & $\begin{array}{l}1 \\
2 \\
3 \\
4 \\
5 \\
6 \\
7 \\
8\end{array}$ & $\begin{array}{l}4.4 \\
4.5 \\
4.6 \\
4.5 \\
4.5 \\
4.5 \\
4.2 \\
4.2\end{array}$ & 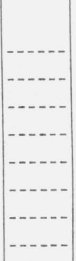 & $\begin{array}{l}36.5 \\
36.6 \\
36.5 \\
36.4 \\
36.5 \\
36.5 \\
36.5 \\
36.4\end{array}$ & $\begin{array}{l}34.2 \\
34.1 \\
34.2 \\
34.2 \\
33.7 \\
33.7 \\
34.5 \\
34.6\end{array}$ & 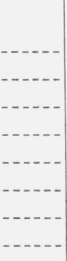 & $\begin{array}{l}8.8 \\
8.8 \\
8.8 \\
8.9 \\
9.1 \\
9.1 \\
9.2 \\
9.2\end{array}$ & $\begin{array}{l}3.3 \\
3.2 \\
3.3 \\
3.3 \\
3.6 \\
3.5 \\
3.3 \\
3.3\end{array}$ & '- & 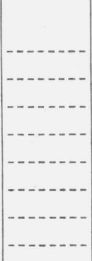 & $\begin{array}{l}12.7 \\
12.8 \\
12.6 \\
12.7 \\
12.6 \\
12.7 \\
12.4 \\
12.4\end{array}$ & - & $\begin{array}{l}--- \\
--- \\
--- \\
--- \\
-- \\
---\end{array}$ & \begin{tabular}{|}
-1 \\
- \\
-
\end{tabular} & $\begin{array}{r}\text { Btu/ft } 3 \\
457 \\
456 \\
456 \\
457 \\
462 \\
461 \\
456 \\
457\end{array}$ & $\begin{array}{r}0.653 \\
.655 \\
.655 \\
.654 \\
.658 \\
.658 \\
.650 \\
.649\end{array}$ \\
\hline & Average......... & -... & 4.4 & & 36.5 & 34.2 & $\ldots$ & 9.0 & 3.4 & & & 12.6 & & & & 458 & .654 \\
\hline & $\left\{\begin{array}{l}\mathrm{O} 1-\mathrm{S} 1-\mathrm{C} 1 \ldots \ldots \\
\mathrm{O} 1-\mathrm{S} 2-\mathrm{C} 1 \ldots \ldots \\
\mathrm{O} 2-\mathrm{S} 3-\mathrm{C} 1 \ldots\end{array}\right.$ & $\begin{array}{l}1 \\
2 \\
3\end{array}$ & $\begin{array}{l}4.8 \\
4.9 \\
4.8\end{array}$ & $\mid-\ldots-1$ & $\begin{array}{r}5.9 \\
6.1 \\
5.9\end{array}$ & $\begin{array}{l}34.2 \\
34.3 \\
34.4\end{array}$ & $\begin{array}{l}30.3 \\
30.4 \\
30.0\end{array}$ & $\begin{array}{l}8.2 \\
8.0 \\
8.2\end{array}$ & $\begin{array}{l}3.4 \\
3.4 \\
3.4\end{array}$ & & & $\begin{array}{l}13.1 \\
13.0 \\
13.3\end{array}$ & & & & $\begin{array}{l}555 \\
552 \\
557\end{array}$ & $\begin{array}{l}.657 \\
.659 \\
.656\end{array}$ \\
\hline \multirow{2}{*}{9} & Average......... & $--\cdot$ & 4.8 & $-\cdots$ & 6.0 & 34.3 & 30.2 & 8.1 & 3.4 & $-\ldots$ & & 13.1 & & & & 554 & .657 \\
\hline & $\left\{\begin{array}{l}\mathrm{O} 1-\mathrm{S} 1-\mathrm{C} 1 \ldots \ldots \\
\mathrm{O} 1-\mathrm{S} 1-\mathrm{C} 2 \ldots \\
\mathrm{O} 1-\mathrm{S} 2-\mathrm{C} 1 \ldots \\
\mathrm{O} 1-\mathrm{S} 2-\mathrm{C} 2 \\
\mathrm{O} 2-\mathrm{S} 3-\mathrm{C} 1 \ldots \\
\mathrm{O} 2-\mathrm{S} 3-\mathrm{C} 2 \\
\mathrm{O} 2-\mathrm{S} 4-\mathrm{C} 1 \\
\mathrm{O} 2-\mathrm{S} 4-\mathrm{C} 2\end{array}\right.$ & $\begin{array}{l}1 \\
2 \\
3 \\
4 \\
5 \\
6 \\
7 \\
8\end{array}$ & $\begin{array}{l}4.5 \\
4.5 \\
4.6 \\
4.6 \\
4.6 \\
4.6 \\
4.6 \\
4.6\end{array}$ & $\begin{array}{r}0.1 \\
.1 \\
.1 \\
.1 \\
.1 \\
.1\end{array}$ & $\begin{array}{l}6.4 \\
6.4 \\
5.8 \\
5.8 \\
5.8 \\
5.8 \\
6.5 \\
6.4\end{array}$ & $\begin{array}{l}35.3 \\
35.3 \\
35.3 \\
35.3 \\
34.8 \\
34.8 \\
35.1 \\
35.1\end{array}$ & $\begin{array}{l}28.9 \\
28.9 \\
29.1 \\
29.1 \\
29.5 \\
29.5 \\
28.7 \\
28.8\end{array}$ & $\begin{array}{l}8.1 \\
8.1 \\
8.2 \\
8.2 \\
8.4 \\
8.4 \\
8.5 \\
8.5\end{array}$ & \begin{tabular}{l|}
3.4 \\
3.4 \\
3.4 \\
3.4 \\
3.4 \\
3.4 \\
3.3 \\
3.3
\end{tabular} & 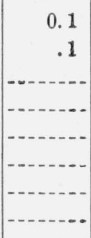 & 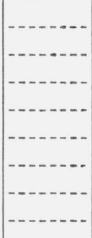 & $\begin{array}{l}13.3 \\
13.3 \\
13.5 \\
13.5 \\
13.4 \\
13.4 \\
13.2 \\
13.2\end{array}$ & & 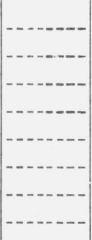 & 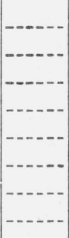 & $\begin{array}{l}558 \\
558 \\
561 \\
561 \\
560 \\
560 \\
555 \\
554\end{array}$ & $\begin{array}{l}.648 \\
.648 \\
.647 \\
.647 \\
.650 \\
.650 \\
.647 \\
.647\end{array}$ \\
\hline \multirow{2}{*}{10} & Average..... & 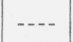 & 4. 6 & .1 & 6.1 & 35.1 & 29.1 & 8.3 & 3.4 & - & - & 13.3 & & & & 559 & .648 \\
\hline & $\left\{\begin{array}{l}\mathrm{O} 1-\mathrm{S} 1-\mathrm{C} 1 \ldots \\
\mathrm{O} 1-\mathrm{S} 1-\mathrm{C} 2 \\
\mathrm{O} 1-\mathrm{S} 2-\mathrm{C} 1 \\
\mathrm{O} 1-\mathrm{S} 2-\mathrm{C} 2 \\
\mathrm{O} 2-\mathrm{S} 3-\mathrm{C} 1 \\
\mathrm{O} 2-\mathrm{S} 3-\mathrm{C} 2 \\
\mathrm{O} 2-\mathrm{S} 4-\mathrm{C} 1 \\
\mathrm{O} 2-\mathrm{S} 4-\mathrm{C} 2\end{array}\right.$ & $\begin{array}{l}1 \\
2 \\
3 \\
4 \\
5 \\
6 \\
7 \\
8\end{array}$ & $\begin{array}{l}4.1 \\
4.1 \\
4.4 \\
4.4 \\
4.7 \\
4.7 \\
4.5 \\
4.5\end{array}$ & 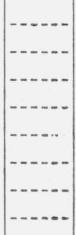 & $\begin{array}{l}6.5 \\
6.7 \\
6.1 \\
6.2 \\
5.9 \\
5.8 \\
6.1 \\
6.1\end{array}$ & $\begin{array}{l}35.6 \\
35.7 \\
35.2 \\
35.2 \\
34.8 \\
35.0 \\
35.2 \\
35.0\end{array}$ & $\begin{array}{l}29.5 \\
29.7 \\
29.9 \\
30.1 \\
30.0 \\
29.8 \\
29.4 \\
29.4\end{array}$ & $\begin{array}{l}7.8 \\
7.5 \\
7.8 \\
7.8 \\
7.8 \\
7.9 \\
7.7 \\
7.7\end{array}$ & \begin{tabular}{l|}
3.1 \\
3.1 \\
3.1 \\
3.0 \\
3.2 \\
3.1 \\
3.2 \\
3.2
\end{tabular} & $\begin{array}{c}.3 \\
.1 \\
.1 \\
\operatorname{Tr} \\
.5 \\
.5\end{array}$ & | & \begin{tabular}{l|}
13.1 \\
13.1 \\
13.4 \\
13.3 \\
13.6 \\
13.7 \\
13.3 \\
13.6
\end{tabular} & | & 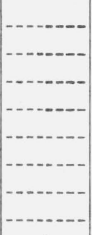 & 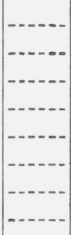 & $\begin{array}{l}555 \\
548 \\
554 \\
549 \\
556 \\
557 \\
562 \\
566\end{array}$ & $\begin{array}{l}.644 \\
.643 \\
.649 \\
.648 \\
.653 \\
.651 \\
.651 \\
.653\end{array}$ \\
\hline \multirow{2}{*}{11} & Average.......... & -..- & 4.4 & $\cdots$ & 6.2 & 35.2 & 29.7 & 7.7 & 3.1 & & & 13.4 & & & & 556 & .649 \\
\hline & $\left\{\begin{array}{l}\mathrm{O} 1-\mathrm{S} 1-\mathrm{C} 1 \ldots \\
\mathrm{O} 1-\mathrm{S} 1-\mathrm{C} 2 \ldots \\
\mathrm{O} 1-\mathrm{S} 2-\mathrm{C} 1\end{array}\right.$ & $\begin{array}{l}1 \\
2 \\
3 \\
4\end{array}$ & $\begin{array}{l}4.0 \\
4.1 \\
4.1 \\
4.0\end{array}$ & 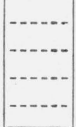 & $\begin{array}{l}5.1 \\
5.4 \\
5.2 \\
5.4\end{array}$ & $\begin{array}{l}33.6 \\
33.5 \\
33.6 \\
33.5\end{array}$ & $\begin{array}{l}32.2 \\
32.0 \\
32.1 \\
32.2\end{array}$ & $\begin{array}{l}8.5 \\
8.4 \\
8.4 \\
8.3\end{array}$ & $\begin{array}{l}3.3 \\
3.1 \\
3.2 \\
3.2\end{array}$ & 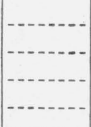 & & $\begin{array}{l}13.4 \\
13.4 \\
13.4 \\
13.4\end{array}$ & 0.1 & & & $\begin{array}{l}565 \\
561 \\
562 \\
561\end{array}$ & $\begin{array}{l}.658 \\
.659 \\
.658 \\
.659\end{array}$ \\
\hline \multirow{2}{*}{12} & Average........... & --- & 4.0 & $-\cdots$ & 5.3 & 33.5 & 32.1 & 8.4 & 3.2 & & & 13.4 & & & & 562 & .658 \\
\hline & $\left\{\begin{array}{l}\mathrm{O} 1-\mathrm{S} 1-\mathrm{C} 1 \ldots \ldots \\
\mathrm{O} 1-\mathrm{S} 1-\mathrm{C} 2 \ldots \ldots \\
\mathrm{O} 2-\mathrm{S} 3-\mathrm{C} 1 \ldots \ldots \\
\mathrm{O} 2-\mathrm{S} 3-\mathrm{C} 2 \ldots \ldots\end{array}\right.$ & $\begin{array}{l}1 \\
2 \\
3 \\
4\end{array}$ & $\begin{array}{l}4.7 \\
4.7 \\
4.7 \\
4.7\end{array}$ & 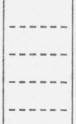 & $\begin{array}{l}5.7 \\
5.7 \\
5.7 \\
5.8\end{array}$ & $\begin{array}{l}36.0 \\
36.1 \\
35.8 \\
35.8\end{array}$ & $\begin{array}{l}30.1 \\
30.1 \\
30.2 \\
30.2\end{array}$ & $\begin{array}{l}7.8 \\
7.7 \\
7.7 \\
7.7\end{array}$ & $\begin{array}{l}3.0 \\
3.0 \\
3.0 \\
3.0\end{array}$ & - & 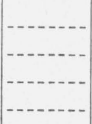 & $\begin{array}{l}12.8 \\
12.7 \\
12.8 \\
12.8\end{array}$ & & & & $\begin{array}{l}542 \\
542 \\
544 \\
543\end{array}$ & $\begin{array}{l}.643 \\
.642 \\
.643 \\
.644\end{array}$ \\
\hline \multirow{2}{*}{13} & Average........... & $-\ldots$ & 4.7 & 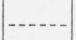 & 5.7 & 35.9 & 30.1 & 7.7 & 3.0 & & & 12.8 & & & & 543 & .643 \\
\hline & $\left\{\begin{array}{l}\mathrm{S} 1 \ldots \\
\mathrm{S} 2 \ldots \ldots \\
\mathrm{S} 3 \ldots \ldots \\
\mathrm{S} 4 \ldots \ldots\end{array}\right.$ & $\begin{array}{l}1 \\
2 \\
3 \\
4\end{array}$ & $\begin{array}{l}4.5 \\
4.5 \\
4.5 \\
4.6\end{array}$ & 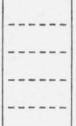 & $\begin{array}{l}7.3 \\
6.8 \\
5.5 \\
5.5\end{array}$ & $\begin{array}{l}25.7 \\
26.3 \\
27.4 \\
27.4\end{array}$ & $\begin{array}{l}37.8 \\
37.8 \\
37.3 \\
37.3\end{array}$ & $\begin{array}{l}8.1 \\
8.1 \\
8.0 \\
8.1\end{array}$ & $\begin{array}{l}3.3 \\
3.3 \\
3.2 \\
3.3\end{array}$ & - & 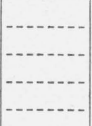 & $\begin{array}{l}12.6 \\
12.6 \\
12.7 \\
12.6\end{array}$ & & 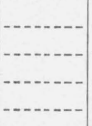 & & $\begin{array}{l}541 \\
543 \\
543 \\
545\end{array}$ & $\begin{array}{l}.617 \\
.618 \\
.615 \\
.617\end{array}$ \\
\hline \multirow{2}{*}{ b 14} & Average........... & $\cdots$ & 4.5 & $-\ldots$ & 6.3 & 26.7 & 37.5 & 8.1 & 3.3 & & & 12.6 & & & - & 543 & .617 \\
\hline & $\left\{\begin{array}{l}\mathrm{O} 1-\mathrm{S} 1-\mathrm{C} 1 \ldots \ldots \\
\mathrm{O} 1-\mathrm{S} 2-\mathrm{C} 1 \ldots \ldots\end{array}\right.$ & $\begin{array}{l}1 \\
2 \\
3\end{array}$ & $\begin{array}{l}4.5 \\
4.5 \\
4.5\end{array}$ & $\begin{array}{l}.03 \\
.03 \\
.03\end{array}$ & $\begin{array}{l}5.9 \\
5.8 \\
5.8\end{array}$ & $\begin{array}{l}36.0 \\
35.6 \\
36.4\end{array}$ & $\begin{array}{l}30.4 \\
30.3 \\
29.7\end{array}$ & $\begin{array}{l}7.6 \\
7.8 \\
7.8\end{array}$ & $\begin{array}{l}3.0 \\
3.0 \\
3.1\end{array}$ & - & & $\begin{array}{l}12.7 \\
13.0 \\
12.8\end{array}$ & & - & $\mid \begin{array}{c}-\cdots-1 \\
-\cdots-1 \\
-\cdots-n\end{array}$ & $\begin{array}{l}540 \\
546 \\
545\end{array}$ & $\begin{array}{l}.643 \\
.645 \\
.639\end{array}$ \\
\hline 15 & Average.......... & $-\cdots$ & 4.5 & -..... & 5.8 & 36.0 & 30.1 & 7.7 & 3.0 & & & 12.8 & & & & 544 & .642 \\
\hline
\end{tabular}

See footnotes at end of table. 
TABLE 1-Continued

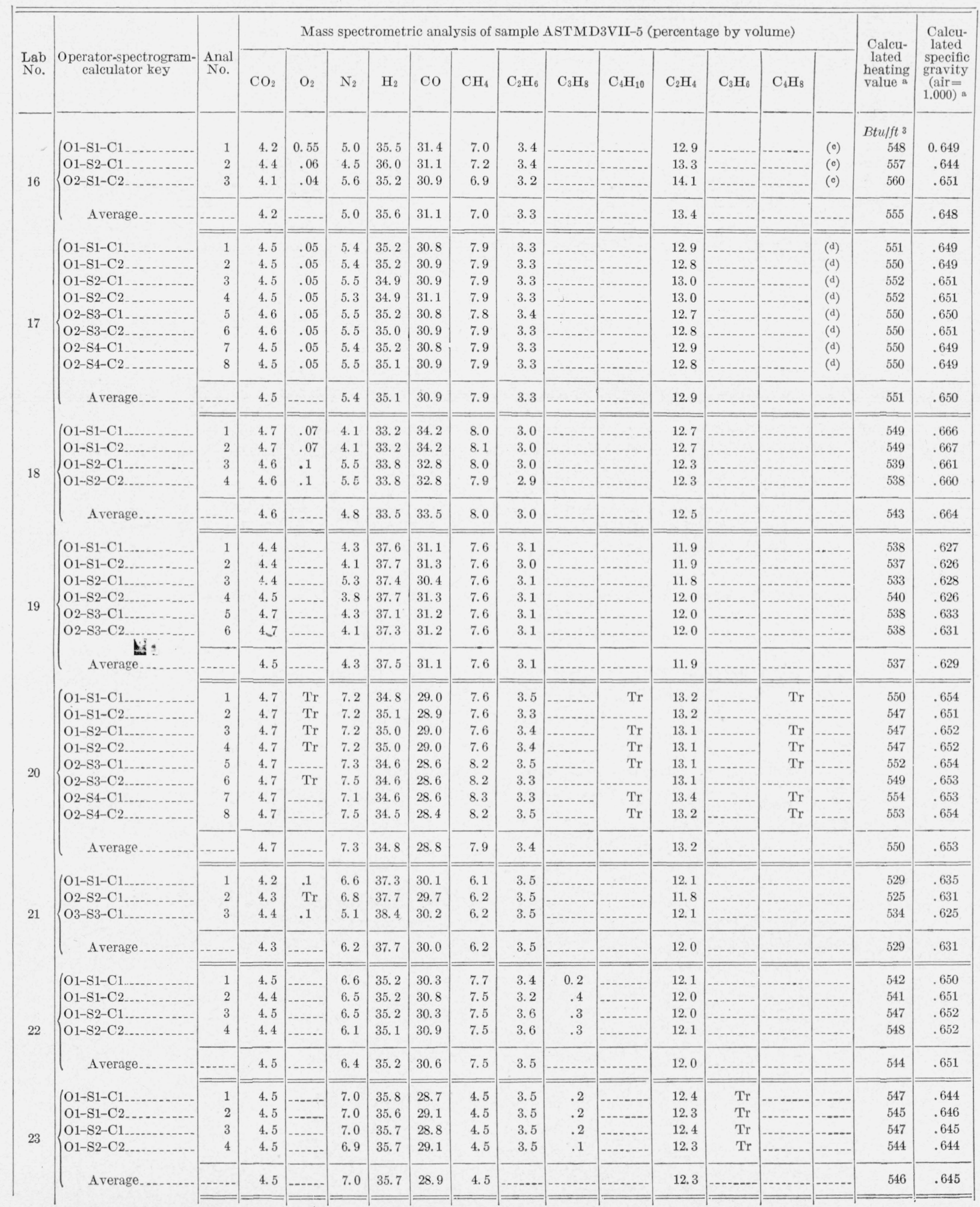

See footnotes at end of table. 
TABLE 1 -Continued

\begin{tabular}{|c|c|c|c|c|c|c|c|c|c|c|c|c|c|c|c|c|c|}
\hline \multirow{2}{*}{$\begin{array}{l}\text { Lab } \\
\text { No. }\end{array}$} & \multirow{2}{*}{$\begin{array}{l}\text { Operator-spectrogram- } \\
\text { calculator key }\end{array}$} & \multirow{2}{*}{$\begin{array}{l}\text { Anal } \\
\text { No. }\end{array}$} & \multicolumn{13}{|c|}{ Mass spectrometric analysis of sample ASTMD3VII-5 (percentage by volume) } & \multirow{2}{*}{$\begin{array}{l}\text { Calcu- } \\
\text { lated } \\
\text { heating } \\
\text { value a }\end{array}$} & \multirow{2}{*}{$\begin{array}{c}\text { Calcu- } \\
\text { lated } \\
\text { specific } \\
\text { gravity } \\
\text { (air= } \\
1.000) \text { a }\end{array}$} \\
\hline & & & $\mathrm{CO}_{2}$ & $\mathrm{O}_{2}$ & $\mathrm{~N}_{2}$ & $\mathrm{H}_{2}$ & $\mathrm{CO}$ & $\mathrm{CH}_{4}$ & $\mathrm{C}_{2} \mathrm{H}_{6}$ & $\mathrm{C}_{3} \mathrm{H}_{8}$ & $\mathrm{C}_{4} \mathrm{H}_{10}$ & $\mathrm{C}_{2} \mathrm{H}_{4}$ & $\mathrm{C}_{3} \mathrm{H}_{6}$ & $\mathrm{C}_{4} \mathrm{H}_{8}$ & & & \\
\hline \multirow[t]{3}{*}{24} & $\left\{\begin{array}{l}\mathrm{O} 1-\mathrm{S} 1-\mathrm{C} 1 \ldots \\
\mathrm{O} 1-\mathrm{S} 1-\mathrm{C} 2 \\
\mathrm{O} 1-\mathrm{S} 2-\mathrm{C} 1\end{array}\right.$ & $\begin{array}{l}1 \\
2 \\
3 \\
4\end{array}$ & $\begin{array}{l}4.6 \\
4.6 \\
4.5 \\
4.6\end{array}$ & $\begin{array}{l}-\cdots \\
-\cdots \\
-\cdots\end{array}$ & $\begin{array}{l}5.7 \\
7.0 \\
5.9 \\
5.3\end{array}$ & $\begin{array}{l}34.8 \\
34.9 \\
35.4 \\
34.8\end{array}$ & $\begin{array}{l}30.5 \\
31.5 \\
30.0 \\
30.8\end{array}$ & $\begin{array}{l}8.1 \\
8.0 \\
8.1 \\
8.1\end{array}$ & $\begin{array}{l}3.2 \\
3.2 \\
3.1 \\
3.2\end{array}$ & - & - & $\begin{array}{l}13.1 \\
10.8 \\
13.0 \\
13.2\end{array}$ & - & - & $\begin{array}{l}(\mathrm{e}) \\
(\mathrm{e}) \\
(\mathrm{e}) \\
\left({ }^{\mathrm{e}}\right)\end{array}$ & $\begin{array}{r}B t u / f t 3 \\
522 \\
519 \\
550 \\
555\end{array}$ & $\begin{array}{r}0.651 \\
.651 \\
.645 \\
.651\end{array}$ \\
\hline & Average_ & 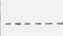 & 4. 6 &..-- & 6.0 & 35.0 & 30.7 & 8.1 & 3.2 & $-\cdots$ & -.... & 12.5 & - . - & - & $\ldots$ & 552 & .649 \\
\hline & $\left\{\begin{array}{l}\mathrm{O} 1-\mathrm{S} 1-\mathrm{C} 1 \ldots \\
\mathrm{O} 1-\mathrm{S} 2-\mathrm{C} 1 \ldots \\
\mathrm{O} 2-\mathrm{S} 3-\mathrm{C} 1 \ldots\end{array}\right.$ & $\begin{array}{l}1 \\
2 \\
3\end{array}$ & $\begin{array}{l}4.5 \\
4.4 \\
4.4\end{array}$ & $\begin{array}{r}0.5 \\
.5 \\
.5\end{array}$ & $\begin{array}{l}8.0 \\
8.0 \\
7.5\end{array}$ & $\begin{array}{l}34.9 \\
35.7 \\
35.0\end{array}$ & $\begin{array}{l}29.0 \\
28.7 \\
29.5\end{array}$ & $\begin{array}{l}7.4 \\
7.3 \\
7.1\end{array}$ & $\begin{array}{l}2.9 \\
2.7 \\
2.9\end{array}$ & - & - & $\begin{array}{l}12.6 \\
12.6 \\
12.6\end{array}$ & - & - & $\left({ }^{\mathrm{f}}\right)$ & $\begin{array}{l}533 \\
527 \\
534\end{array}$ & $\begin{array}{l}.652 \\
.645 \\
.649\end{array}$ \\
\hline \multirow{2}{*}{25} & Average & -..- & 4. 4 & .5 & 7.8 & 35.2 & 29.1 & 7.3 & 2.8 & -.... & - & 12.6 & $\ldots$ & - & $-\ldots$ & 532 & .649 \\
\hline & $\left\{\begin{array}{l}\mathrm{O} 1-\mathrm{S} 1-\mathrm{C} 1 \ldots \ldots \\
\mathrm{O} 1-\mathrm{S} 2-\mathrm{C} 1 \ldots \ldots\end{array}\right.$ & $\begin{array}{l}1 \\
2\end{array}$ & $\begin{array}{l}4.4 \\
4.4\end{array}$ & $\begin{array}{l}.4 \\
.4\end{array}$ & $\begin{array}{l}8.8 \\
8.8\end{array}$ & $\begin{array}{l}33.9 \\
33.9\end{array}$ & $\begin{array}{l}28.8 \\
28.8\end{array}$ & $\begin{array}{l}8.0 \\
8.0\end{array}$ & $\begin{array}{l}2.8 \\
3.0\end{array}$ & - & - & $\begin{array}{l}12.9 \\
12.7\end{array}$ & -.... & - & $-\ldots$ & $\begin{array}{l}533 \\
533\end{array}$ & $\begin{array}{l}.659 \\
.659\end{array}$ \\
\hline \multirow{2}{*}{26} & Average & $\ldots$ & 4.4 & --- & 8.8 & 33.9 & 28.8 & 8.0 & 2.9 & - & - & 12.8 & -..... & - & $\cdots$ & 533 & .659 \\
\hline & $\left\{\begin{array}{l}\mathrm{S} 1 \ldots \ldots \ldots \\
\mathrm{S} 2 \ldots \ldots \\
\mathrm{S} 3 \ldots \ldots\end{array}\right.$ & $\begin{array}{l}1 \\
2 \\
3 \\
4\end{array}$ & $\begin{array}{l}4.3 \\
4.3 \\
4.4 \\
4.4\end{array}$ & $\begin{array}{l}-\cdots \\
-\cdots \\
-\cdots\end{array}$ & $\begin{array}{l}5.4 \\
5.3 \\
4.9 \\
5.0\end{array}$ & $\begin{array}{l}34.5 \\
34.6 \\
34.9 \\
34.5\end{array}$ & $\begin{array}{l}31.1 \\
31.2 \\
31.2 \\
31.3\end{array}$ & $\begin{array}{l}8.1 \\
8.1 \\
8.1 \\
8.1\end{array}$ & $\begin{array}{l}3.2 \\
3.2 \\
3.1 \\
3.1\end{array}$ & - & - & $\begin{array}{l}13.4 \\
13.3 \\
13.4 \\
13.6\end{array}$ & - & - & $\begin{array}{l}-\cdots \\
\cdots-- \\
\cdots--\end{array}$ & $\begin{array}{l}558 \\
557 \\
558 \\
560\end{array}$ & $\begin{array}{l}.652 \\
.651 \\
.649 \\
.653\end{array}$ \\
\hline 27 & Average........ & $\ldots-$ & 4.3 & $\ldots$ & 5.2 & 34.6 & 31.2 & 8.1 & 3.2 & 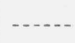 & - n. & 13.4 & - n. & $\ldots$ & $-\cdots$ & 559 & .651 \\
\hline
\end{tabular}

- Factors used in computations of $\mathrm{Btu} / \mathrm{Ft}^{3}$ and sp gr:

\begin{tabular}{|c|c|c|c|c|c|}
\hline Components & $\mathrm{Btu} / \mathrm{ft}^{3}$ & Sp Gr & Components & $\mathrm{Btu} / \mathrm{ft}^{3}$ & $\mathrm{Sp} \mathrm{Gr}$ \\
\hline $\mathrm{CO}_{2} \ldots$ & & 1.5290 & $\mathrm{CH}_{4} \ldots \ldots$. & 997.4 & 0.5544 \\
\hline $\mathrm{O}_{2} \ldots \ldots$ & 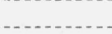 & 1. 1053 & $\mathrm{C}_{2} \mathrm{H}_{4} \ldots \ldots$ & 1587.0 & .97487 \\
\hline $\mathrm{N}_{2} \ldots \ldots \ldots \ldots$ & - & .97208 & $\mathrm{C}_{2} \mathrm{H}_{6} \ldots \ldots \ldots$ & 1759.0 & 1.0493 \\
\hline $\mathrm{CO}$ & 316.1 & .96713 & $\mathrm{C}_{3} \mathrm{H}_{6} \ldots \ldots \ldots$ & 2339.0 & 1.45 \\
\hline $\mathrm{H}_{2} \ldots \ldots$ & 319.4 & .06952 & $\mathrm{C}_{3} \mathrm{H}_{8} \ldots \ldots$ & 2528.0 & 1. 5624 \\
\hline
\end{tabular}

b Laboratories 7 and 14 used Westinghouse instruments; all others used Consolidated instruments.

- Reported $0.1 \% \mathrm{C}_{2} \mathrm{H}_{2}$ and $0.04 \% \mathrm{C}_{3}+$.

d Reported $0.05 \% \mathrm{C}_{3}{ }^{+}$.

- Reported trace $\mathrm{C}_{3}{ }^{+}$.

1 Reported $\mathrm{C}_{3}{ }^{+}, 0.2,0.1,0.3$.

Washington, December 6, 1949. 